\title{
Regional approach to achieving sustainable development goals: legal analysis of the EAEU experience in creating a common labor market in its relationship with SDG 8
}

\author{
Dmitry Ivanov, Mariia Levina* \\ Moscow State Institute of International Relations (University), MFA Russia, 119454, pr. \\ Vernadskogo, 76, Moscow, Russia
}

\begin{abstract}
The article is devoted to the study of the role of the regional component in implementation of the Agenda for Sustainable Development until 2030. Achievement of the 17 Goals and 169 targets in the field of sustainable development indicated in it can hardly be conditioned only by the successful and effective policy of each of the UN member states in this direction. This is explained, first of all, by the fact that the implementation of the Agenda envisages both the interaction of countries at a universal level and largely depends on their regional cooperation, including through integration associations. Wherein, the study of the relevant experience of the Eurasian Economic Union as one of the largest regional associations of economic integration is of considerable interest in this matter. The authors consider practical achievement of the mentioned Goals, primarily Goal 8, through the prism of ensuring freedom of movement of labor within the Union and the effective functioning of its common labor market.
\end{abstract}

\section{Introduction}

The Agenda for Sustainable Development until 2030 approved by the UN General Assembly on September 25, 2015 (hereinafter - the Agenda) ${ }^{1}$ is aimed at ensuring the stable and progressive development of the world. Achievement of such a task mainly depends on improvement of its three key components - economic, social and environmental, which are detailed and grouped by the authors of the policy document into 17 Goals (hereinafter referred to as the Sustainable Development Goals, SDGs) and 169 targets.

Although the Agenda is comprehensive, and the priorities outlined in it are global and universally applicable, the role of regional cooperation in the work to achieve them remains quite high. This conclusion was first formulated in 2012, when the UN General Assembly

\footnotetext{
* Corresponding author: marylevis95@mail.ru

${ }^{1}$ UN General Assembly, Transforming our world: the 2030 Agenda for Sustainable Development [Electronic resource]: 21 October 2015, A/RES/70/1, available at https://undocs.org/A/RES/70/1
} 
in its resolution 66/288 "The Future We Want"2 determined that regional mechanisms can complement and improve practical steps taken at the national level to ensure sustainable development, and regional and subregional organizations can play a significant role in realizing the economic, social and environmental components of such development. Subsequently, this approach was implemented in paragraph 21 of the Agenda, which recognizes "the importance of regional and subregional factors, regional economic integration and synergies in the field of sustainable development. Regional and subregional mechanisms can help to effectively translate sustainable development strategies into concrete actions at the national level"3.

From a practical point of view, it is important to note that the current negative trends in the global economy caused by the consequences of the new coronavirus infection, cast doubt on the possibility of implementing traditional national programs based, among other things, on achieving the Sustainable Development Goals [Larionova, 2020: 178]. In addition, the pandemic revealed significant vulnerability of the entire global financial system [Streimikiene, Kaftan, 2021]. In this regard, formation by states of "green" and inclusive economies in accordance with the goals and objectives of the Agenda increasingly depends on their membership and active participation in regional integration associations as platforms with effective political and economic tools to overcome global challenges. An additional argument is the fact that at the regional and subregional levels, countries have more coinciding national interests and priorities, due to which they are able to jointly and more substantively solve certain problems [Dudykina, 2017: 148].

Wherein, the study of the relevant experience of the Eurasian Economic Union (hereinafter referred to as the EAEU, the Union) as a major regional player is only included in the range of scientific interests of domestic scientists, and therefore the degree of study of this issue remains not so significant. Wherein, the Eurasian partnership is becoming an increasingly promising format of interstate cooperation, within which the countries of the post-Soviet space are the main beneficiaries of such interaction [Vinokurov 2017:67]. Namely, Armenia, Belarus, Kazakhstan, Kyrgyzstan and Russia as member states of the Union have achieved certain success in ensuring the synergy of national development plans and programs, consistently reducing barriers, exemptions and restrictions on the EAEU markets, as well as creating conditions for the formation of a free competitive environment. No less important is the fact that the heads of government of the allied states adopted in 2020 a package of measures to ensure the vital needs of the population, maintain mutual trade, freedom of movement of goods in the context of the COVID-19 pandemic and create conditions for subsequent economic growth. ${ }^{4}$ Such socio-economic achievements of the Union can be considered with confidence as practical evidence of its commitment to the Sustainable Development Goals.

\section{Study Methods}

Analysis and synthesis as methods of formal logic are mainly the methodological basis of this paper. When writing the article, the authors were also guided by the comparative legal research method when studying documents related to the adoption and further implementation of the Agenda for Sustainable Development for the period up to 2030, as

\footnotetext{
${ }^{2}$ UN General Assembly, The future we want [Electronic resource]: 11 September 2012, A/RES/ 66/288, available at https://undocs.org/A/RES/66/288

${ }^{3}$ UN General Assembly, Transforming our world: the 2030 Agenda for Sustainable Development, p. 21

${ }^{4}$ For more details see Annual report of the Eurasian Economic Commission "EAEU against Covid19. Stronger together"
} 
well as international treaties and acts of the EAEU bodies that constitute the law of the Union.

\section{Results of the Study}

Eurasian Economic Union, as an international organization for regional economic integration has become the first regional association to submit a report on the indicators of achievement of Goals in the field of sustainable development in the region EAEC for its consideration at the Policy Forum on Sustainable Development of high level in 2017 After two years on the sidelines at the Forum 2019 the Eurasian Economic Commission (hereinafter referred to as the EEC, the Commission) has presented its own methodology for assessing indicators of SDG achievement, taking into account integration features. Therefore, the need to achieve the Goals in the post-Soviet space is confirmed not only in the national action plans of individual states, but also within the framework of the integration association established in the designated region.

The EAEU's commitment to the Sustainable Development Goals is enshrined and detailed in the law of the Union ${ }^{5}$, which, as a phenomenon mediated by international treaties and/or acts of the bodies of an international organization, is natural, is a part of international law [Anufrieva 2016:58]. However, due to the fact that analyzing the legal basis EAEC in its compliance with all 17 Goals in the field of sustainable development is not entirely possible in this study, the authors stopped at addressing this issue in the context of the SDG 8 "Promotion of sustained, inclusive and sustainable economic growth, full and productive employment and decent work for all", while focusing on issues related to decent work.

Namely, in Article 4 of the Treaty on the EAEU of May 29, 2014 as a system-forming act of the entire legal system of the Organization [Kapustin 2014: 105], the main goals of the Union are enshrined, which in many respects are similar to the above Goal. Therefore, creation of conditions for stable development of the economies of the EAEU member states in the interests of improving the living standards of their population and the desire to form a single market for goods, services, capital and labor resources within the Union $^{6}-$ these two goals of the Union are fully correlated with SDG 8 and, namely, correspond to its paragraph 8.1 "to maintain economic growth per capita" and paragraph 8.5 "to ensure full and productive employment and decent work for all women and men, including young people and people with disabilities, and equal pay for work of equal value" ${ }^{\text {"7 }}$.

In addition, the issues of achieving SDG 8 are reflected in the Main Directions of Economic Development of the EAEU until 2030 approved by the Decision of the Supreme Eurasian Economic Council dated October 16, 2015 No. $28^{8}$. However, it is necessary to consider that this document is of a recommendatory nature and determines the promising

\footnotetext{
${ }^{5}$ Article 6 of the Treaty on the Eurasian Economic Union of May 29, 2014 introduces the concept of "Union law", which are: constituent agreement; international treaties concluded within the Union and between the Union and a third party; decisions and orders of the Supreme Eurasian Economic Council, the Eurasian Intergovernmental Council and the Eurasian Economic Commission, adopted within their competence. More details about the "Union law" can be found on the EAEU Legal Portal https://docs.eaeunion.org/ru-ru

6 Article 4 of the Treaty on the Eurasian Economic Union of May 29, 2014 Доступ: https://docs.eaeunion.org/docs/ru-ru/0003610/itia_05062014

${ }^{7}$ UN General Assembly, Transforming our world: the 2030 Agenda for Sustainable Development, $p$. 19-20.

${ }^{8}$ Decision of the Supreme Eurasian Economic Council dated October 16, 2015 No. 28 "On the Main Directions of Economic Development of the Eurasian Economic Union"; Access:

https://eec.eaeunion.org/upload/medialibrary/59e/Reshenie-_28-ONER.pdf
} 
areas of the Union's socio-economic development, which its member states strive to implement through use of the integration potential of the association and competitive advantages. Its section $\mathrm{V}$, among the integration measures and actions that contribute to achievement and maintenance of high-quality and stable economic growth of the Member States and the Union as a whole, include ensuring macroeconomic stability, innovative development and modernization of the economy, as well as the development of human resources. It seems that these areas of economic development also coincide with the SDG 8.

In this regard, the Strategic Directions for Development of Eurasian Economic Integration until 2025 approved by the Decision of the Supreme Eurasian Economic Council No. 12 of December 11, 2020, are no less important. The introductory part of the document states that the agreed directions correspond to the goals of sustainable and inclusive economic development of each member state and provide for creation of conditions for the advanced development of their economies, increase in employment and the provision of decent work for all social groups of the population, which further confirms the Union's programmatic commitment to achieving the SDGs.

However, it shall not be limited to an analysis of declarative provisions of Union law recording it following with the Goals in the field of sustainable development, but also to study the practical implementation of the SDG 8 in respect of the work within the framework of the EAEC.

Article 4 of the Treaty on the EAEU establishes creation of a single labor market as one of the main goals of the Union. In this regard, provisions of the Treaty, namely, section XXVI, bring the legal regulation of the union labor market to a high level, significantly expanding the rights of citizens of the Member States when they carry out labor activities in the territory of the EAEU [Krylov, Nadirova 2017:50], [Khabrieva 2019:300]. Freedom of movement within the Union is becoming key, providing the following preferences for the workers of the member states: non-proliferation of measures to protect the national labor market, including in the form of quotas; exemption from the need to obtain a work permit and fill out migration cards when crossing the border of another member state of the Union under one of the valid documents that allows the stamping of border control authorities; the ability to conclude civil agreements on a par with employment contracts. The mutual and direct - without any additional procedures - recognition of educational documents, with the exception of the pedagogical, legal, medical or pharmaceutical fields is also important. In addition, the workers of the Member State are guaranteed with the right to own, use and dispose of their property, to protect property, as well as to the smooth transfer of funds. In this context, it is important to consider, in general, that the peculiarity of the legal regulation of the activities of workers of the Union member states is that they are legally equal with the citizens of the states of employment according to a number of indicators [Ivanchak 2015:58-64].

In this case, the memorandum of association not only sets out the general approach of states - members of the EAEC to the legal regulation of a common labor market, but also regulates the issues of social, health and pension systems. It is important to provide the workers of the Member States, on the same conditions and in the same manner as the citizens of the state of employment, with compulsory insurance against temporary disability and in connection with maternity, against accidents at work and occupational diseases, as well as compulsory health insurance. In addition, this category of persons is guaranteed with provision of emergency and urgent medical care.

Preservation and implementation of workers' pension rights, as well as the export of their pensions is regulated by a separate Agreement on pension provision of workers of the EAEU member states dated December 20, 2019. The key provision of the document is the principle of equal pension rights of workers, 
which provides for the formation and implementation of pension rights of workers of the Union member states on the same conditions and in the same manner as for citizens of the state of employment.

Therefore, the Union's common labor market appears to be one of the areas where its member states have been able to achieve the greatest results [Vinokurov 2017:67]. Citizens of the union states are guaranteed and ensured with a special, expanded, scope of rights that allows us to state the existence within the EAEU of "reliable and safe working conditions for all workers, including migrant workers, especially women migrants, and persons without stable employment", as this is provided for in paragraph 8.8 of Sustainable Development Goal No. 8. However, the socio-economic problems caused by the COVID19 pandemic that the workers of the EAEU member states have faced over the past two years (a significant reduction in migration flows due to the closure of borders and a decrease in income employment" (paragraph 8.5 of SDG 8), which will require additional coordinated efforts from its member states.

\section{Discussion of Results}

With regard to forecasting the prospects for implementation of the Sustainable Development Goals by 2030, we note that their achievement will largely be due to the effective interaction of states at the regional level, as well as within the framework of their membership in integration associations. Acceleration of the economic, social and "ecological" development of an individual state will be possible to a certain extent through use of the experience and tools possessed mainly by the integration association. In this regard, one of the flagships in achieving the SDGs is becoming the Eurasian Economic Union, the legal basis of which was initially based on its commitment to the Sustainable Development Goals. Although the dynamics of implementation of individual SDGs by it, including in the field of ensuring full and productive employment, is positive (largely due to creation of an extensive and stable legal framework that regulates in detail the common labor market), maintaining high indicators in this direction will require significant efforts on the part of its Member States due to the socio-economic challenges posed by the new coronavirus pandemic.

\section{Conclusions}

According to the results of the study, we can state a high degree of regulation in the policy documents in the field of SDGs of issues related to the role of the regional component in their achievement. Thus, the value of regional and subregional factors, as well as regional economic integration, originally indicated in paragraph 21 of the Agenda, was subsequently reaffirmed in the Political Declaration of the High-Level Political Forum on Sustainable Development convened under the auspices of the UN General Assembly in 2019. However, the significance of the regional component is not only determined in the texts of declarative documents, but is also practically provable. Namely, the authors of the article were able to confirm this thesis by analyzing the activities of the Eurasian Economic Union in this direction. The study was based on the Union's experience in building a common labor market as one of the practical steps in achieving SDG 8 dedicated to promoting progressive, inclusive and sustainable economic growth, full and productive employment and decent work for all. The high level of legal regulation of migration processes within the EAEU made it possible to create all the foundations for the formation and further successful development of the common labor market of the Union, within the framework of which any form of discrimination in employment is excluded for citizens of the Union 
states, the conditions of entry and stay are significantly "liberalized", as well as guaranteed social and health care. Therefore, the integration potential of the Union, which it has realized, including in the field of ensuring the freedom of movement of labor resources, directly correlates with the tasks of the world community in the field of sustainable development.

\section{References}

1. L. P. Anufrieva, EAES $i$ «pravo EAES» v mezhdunarodno-pravovom izmerenii, Moskovskij zhurnal mezhdunarodnogo prava, 4, 48-62 (2016)

2. I. P. Dudydkina, Mezhdunarodno-pravovoe soderzhanie koncepcii ustojchivogo razvitiya (analiz zarubezhnyh doktrin), Moskovskij zhurnal mezhdunarodnogo prava, 2 (106), 144-153 (2017)

3. A. I. Ivanchak, Pravovoe regulirovanie truda rabotnikov-migrantov stran EAES, Pravo i upravlenie: XXI vek, 3, 84-90 (2015)

4. A. Ya. Kapustin, Dogovor o Evrazijskom ekonomicheskom soyuze - novaya stranica pravovogo razvitiya evrazijskoj integracii, Zhurnal rossijskogo prava, 12, 98-101 (2014)

5. M. V. Larionova, Spasti CUR. Ukreplenie partnerstva dlya dostizheniya CUR v postpandemicheskom cifrovom mire, Vestnik mezhdunarodnyh organizacij, 4, 163-188 (2020)

6. K. D. Krylov, A. K. Nadirova, K voprosu o vliyanii Evrazijskogo ekonomicheskogo soyuza na trudopravovuyu integraciyu, Trudovoe pravo v Rossii i za rubezhom, 4, 5053 (2017)

7. T. Ya. Habrieva, Migracionnoe pravo: sravnitel'no-pravovoe issledovanie: monografiya (2019)

8. E. Vinokurov, Eurasian Economic Union: Current state and preliminary results, Russian Journal of Economics, 3 (1), 54-70 (2017)

9. E. Vinokurov, Pragmatic Eurasianism: Prospects for Eurasian Integration, Russia in Global Affairs, 2(2), 87-96 (2013)

10. D. Streimikiene, V. Kaftan, Green finance and the economic threats during COVID-19 pandemic, Terra Economicus, 19 (2), 105-113 (2021) 